\section{Flood Detection Control System Design Based on SMS Gateway}

\author{
Iqbal Kamil Siregar ${ }^{1}$, Jhonson Efendi Hutagalung ${ }^{2}$, Bachtiar Efendi ${ }^{3}$, Herman \\ Saputra $^{4}$ \\ ${ }^{1,3,4}$ Sistem Komputer, STMIK Royal Kisaran, Sumatera Utara \\ ${ }^{2}$ Steknik Komputer, STMIK Royal Kisaran, Sumatera Utara
}

\begin{tabular}{|c|c|}
\hline Article Info & ABSTRACT \\
\hline Article history: & \multirow{6}{*}{$\begin{array}{l}\text { Flood concern everybody in every flood area. It makes the researchers interest } \\
\text { to take the research about flood detection system, especially in rivers by using } \\
\text { mobile phone facilities. The procedure of this tool is if the flood rise due to } \\
\text { overflow of the river, then the river guard will receive SMS to tell the people } \\
\text { to anticipate the flood by sounding the alarm until the entire riverbank area. } \\
\text { This SMS delivery is via connection to telecommunications network using } \\
\text { SMS gateway module. This tool can be used as a flood emergency which is } \\
\text { installed at river location points where sensors and control devices are } \\
\text { permanently installed. This research has been successful and has been well } \\
\text { tested in its implementation. }\end{array}$} \\
\hline Received 11 30, 2021 & \\
\hline Revised 12 13, 2021 & \\
\hline Accepted 12 17, 2021 & \\
\hline Keywords: & \\
\hline $\begin{array}{l}\text { Sensor } \\
\text { Flood }\end{array}$ & \\
\hline
\end{tabular}

SMS

Gateway

This is an open access article under the CC BY-SA license.

\author{
Corresponding Author: \\ Jhonson Efendi Hutagalung \\ Teknik Komputer \\ STMIK Royal Kisaran \\ Sumatera Utara, Indonesia \\ Email: jhonefendi12@yahoo.co.id \\ (C) The Author(s) 2021
}

\section{Introduction}

Rapid technology growth is along with rapid platform increase of electronic device growth in accordance with the development of hardware and software in used. Computer technology beside used for lifestyle necessity, it also used to help a lot in all kinds of work, including early detection of flood hazards. In 2021, there have been occured flood in many residence. One of them is in Asahan North Sumatera at Desa Sei Silau Tua, at Sei Silau Barat, and at Karya Ambalutu. This flood affect for financial loss, mental loss even lives losse. which has resulted in hundreds of people experiencing material and life losses. This is due to the irregular flow of rivers and the drainage of housing or residents, resulting in overflow water in the [1]. Therefore, watersheds that often occur the flood require a system that can inform an initial increase in river water which can be monitored from the Regional Disaster Management Agency to reduce or cope the floods to not take many victims, so that the resident preparedness in dealing with floods increases [2].

From the explanation above, the researcher researchers made a tool to detect the level of river water when it will overflow into residential areas in use of automatic electronic devices. The component used is Arduino Uno microcontroller which is connected to ultrasonic sensor that can detect the water level of the river. When the river water rises to 1 meter in height, the device will communicate with Telkomsel's communication from sensor which will be sent via SIM 800 to the server and send SMS to the Disaster Management Agency by knowing the initial warning of this short message and it can avoid casualties and material [3]. 


\section{Research Methodology}

The process of drawing, planning and sketching or arranging of various elements, the system design with hardware and software.

a. Preparation of Tools and Materials

Material is a component to make a tool to be designed, it will be assembled or connected one by one so that it can detect the human heart rate by activating the sensor. All tools and materials are provided by purchasing them either directly at the seller's shop or online. Materials and supporting tools obtained to complete the entire system created.

b. Layout Design

In layout design, the position of each component is planned. This design is done by drawing the circuit and followed by the component layout design, electronics design application software, for example circuit wizard and proteus version 8.0.

c. Interface Design

The user interface display program is designed using the principle of being easy to use and easy to understand by the user in the interface design. For designing the interface, it is created and installed on Android smartphone.

d. Testing of System

Hardware and software will be built, it need to be tested the system can run or no, and can repair the execution process in the system.

e. Implementation System

After the system was tested, then the system will be applied to run the system based on the results of the analysis and design. From the results of this implementation, system development can be carried out according to system requirements. So that the work operation process of the system can run well.

\section{Result and Discussion}

\subsection{System Analysis}

This system is used to provide information via SMS to mobile phone of flood control guard and to find out the condition of the overflowing river with the river water level exceeding 1 meter. For activation, SMS is sent when the sensor detects overflow of water level [4]. For system implementation, it is necessary to test the system. This system is known remotely so that it speeds up us to complete it, this tool consists of microcontroller circuit, as the Arduino Uno control center, Ultrasonic Sensor, SIM 800 circuit, Mobile phone and other software or programs. To control the designed tool works as expected, its necessary to test hardware and software[5].

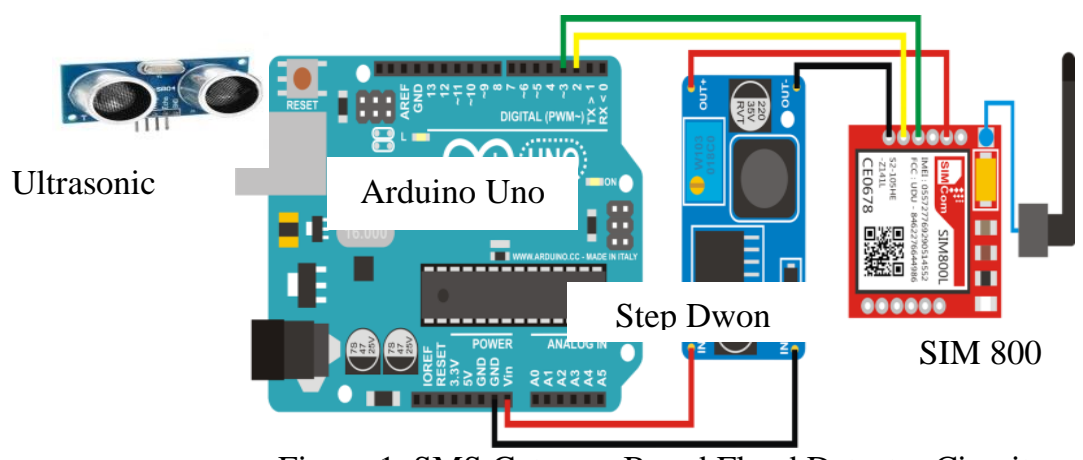

Figure 1. SMS Gateway Based Flood Detector Circuit

This test is carried out by initializing process according to the type of microcontroller used in this program using Arduino Uno microcontroller. After the initialization process is successful, the next step is initializing the connection between microcontroller and other system circuits. It also requires setting the minimum system port connected to the laptop/computer, by selecting Com 6 to be used as the interface to the device, and the baud rate is 9600 . This program will run when sending SMS to cellphone, so that the microcontroller provides input to SIM 800 with beam of frequency [6].

\subsection{Software Design}

Software used in the flood detection system using mobile phone is Arduino Idea Programming with $\mathrm{C}$ language [7]. After the program is designed, the program is directly uploaded to microcontroller via PC or laptop to save the program to Arduino chip. To test the program designed successfully, it has to compile 
the program to know any errors or no. Then the sketch is uploaded to be saved to Arduino chip [8]. After that, it will be received SMS with the words "There will be a flood" so the buzzer sounds and the flood disaster management guard will immediately notify all the residents of the suburbs.

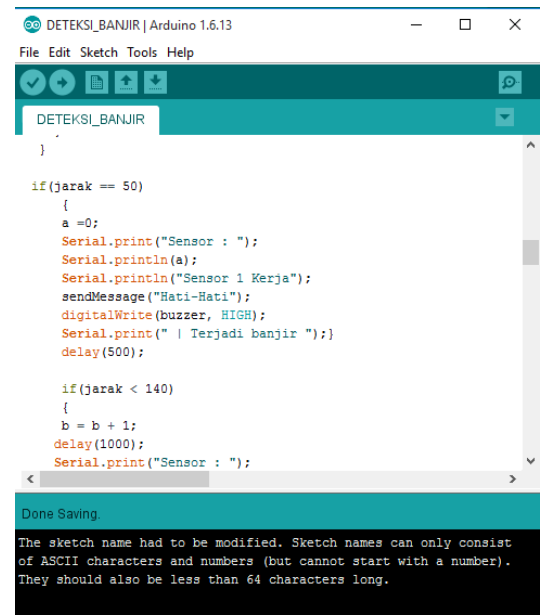

Figure 2. Flood Detection Program Coding

\subsection{Hardware Testing}

Program testing is done by filling out the designed program using Arduino Ide application [9]. After verifying the program, it will be downloaded into arduino uno IC program. The power supply used is full wave power supply. Testing the power supply is done by providing an alternating input voltage (AC) of 220 Volts directly from PLN. For the output voltage of the transformer that has been connected to the power supply circuit, measurements were made for tap 12-CT-12 on the output voltage of the power supply. Microcontroller testing is done by programming microcontroller using $\mathrm{C}$ language programming language, and testing the microcontroller used can work well or not. To ensure the ultrasonic sensor can detect rising river water levels by connecting the sensor circuit to Arduino Uno's input pins, they are Vcc, Gnd and pin 6 (trig) and pin7 (echo) pins. Sensor testing can be done by providing increase in water in the container above the sensor, then the sensor will detect increase in altitude [10].

Table 1. Sensor Test

\begin{tabular}{cccc}
\hline NO & Sensor $(\mathbf{m})$ & Ultrasonic Sensor & Information \\
\hline 1 & $<1$ & Active & Voltage 5 Volt \\
\hline 2 & $>1$ & Non-Active & Voltage 0 \\
\hline
\end{tabular}

For testing mobile phones that are connected to SMS gateway, it is done by making infrared wave connection system. The connection is made on Telkomsel, it is GSM via SIM 808 device on cellphone. After everything is made and tested one by one,the next step is to combine all the circuits or systems made both software and hardware become an application tool for flood detection system based on SMS Gateway as a flood detector. from rising river levels. So that it can be known by using incoming SMS to the river guard. After that, testing is carried out to know the tool can run as desired to detect the detected increase in river water [11].

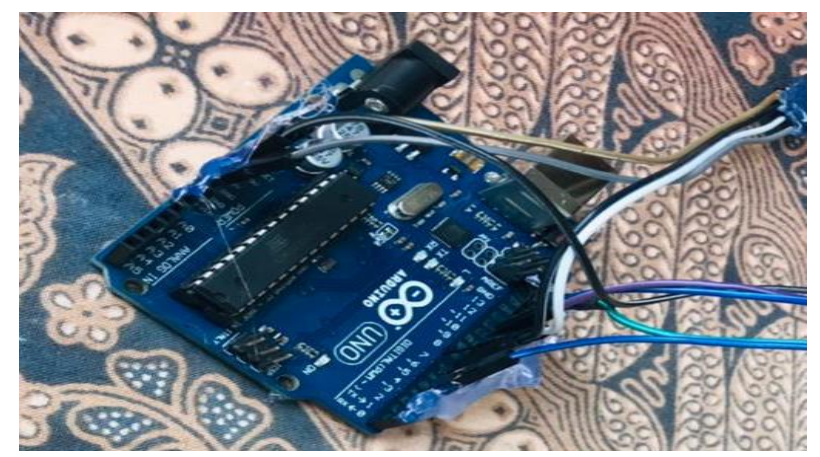

Figure 3. Arduino Microcontroller Circuit 
Figure 3 above is Arduino Uno microcontroller, it used to control the entire system using the program downloaded to the IC Chip.

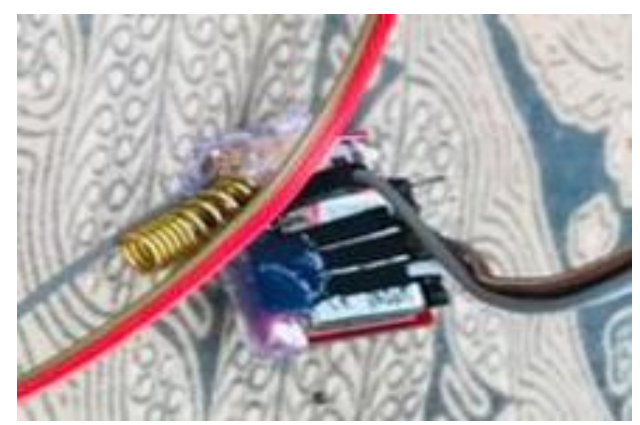

Figure 4. SIM 800

Figure 4 is SIM 800 which is used to connect the device to GSM network, in this case is TELKOMSEL, so that SMS will be sent to the river guard cell phone or the Disaster Management Agency [12].

3.4 Result Analysis

With the detection system works as follows:

1. ON/OFF switch to activate the flood detection system. If it is $\mathrm{ON}$, the system will activate the fan, if it is OFF, the system will not be active.

2. The sensor detects increase in water level so that SIM 800 will work sending SMS to the guard's cellphone.

3. The system will sound a louder alarm to provide information about the occurrence of floods quickly and with wide range. The system will trigger sending SMS through the gateway to the river guard's cellphone to immediately notify all residents around the river.

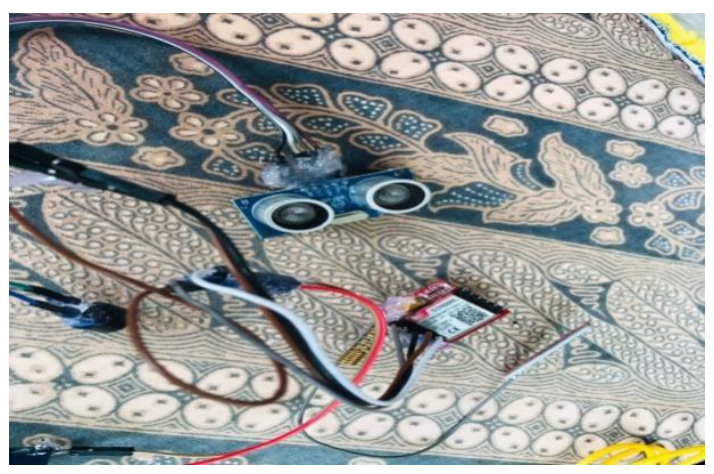

Figure 5. Components of Flood Detection System

The sensor will detect the water level of the river using ultrasonic sensor connected to Arduino Uno. 


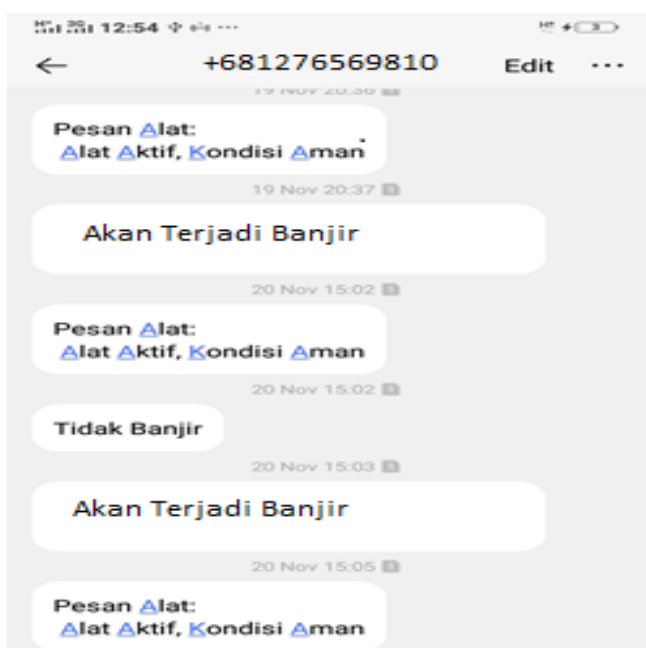

Figure 6. Incoming SMS To River Guard

When there is overflow of river water, the system will automatically send SMS to the guard with the message "there will be a flood". This SMS goes to the cellphone of the river's guard or the Disaster Management Agency to immediately notify all residents around the river[13]

\section{Conclusion}

From the discussion above, it can be conclude that:

1. River water level detection system can work well. The components used as a detection system are ultrasonic sensors, sms gateway modem and mobile phones as SMS recipients.

2. With this river water level detection system, flood disaster management guards can find out the condition of the river even though it is in far place as long as it pays attention to the presence of cellular telephone signals (TELKOM/GSM).

3. The existence of a flood detection system can minimize the loss of life and loss of financial or material from the residents around the river.

4. The ultrasonic sensor functions to instruct SIM 800 to send SMS to cellphone of river's guard to notify the residents that the flood will occur by sounding an alarm that can be heard from a long distance from the flood position.

\section{Acknowledgement}

The researchers thank to the Director General of Higher Education (Dirjen DIKTI) through BELMAWA for the PHP2D program. The researchers can publish related journals about the development of Desa Hessa Perlompongan, Kecamatan Air Batu, Kabupaten Asahan, where a flood detection system has been implemented in that area.

\section{References}

[1] Faisal Alfaeru. 2016. "Implementasi Sensor Akselerometer Dan Modul Gps Untuk Rancang Bangun Smartbike”. Jurnal Ilmu-Ilmu Teknik - Sistem , Vol. 12 No. 3.

[2] Ade Mubarok, dkk. 2018. "Sistem Keamanan Rumah Menggunakan RFID, Sensor PIR dan Modul GSM Berbasis Mikrokontroler". Jurnal Informatika, Vol.5 No.1, pp. 137 144 ISSN: 2355-6579 E-ISSN: 2528

[3] Harnas Alfath, 2017. "Alat Ukur Kadar Asap Rokok dalam Ruangan dengan menggunakan Sensor MQ 2 dengan Tampilan LCD Berbasis Arduino Uno”. Departemen Fisika Kertas Karya Diploma (Metrologi dan Instrumentasi)

[4] Faisal Alfaeru. 2016. "Implementasi Sensor Akselerometer Dan Modul Gps Untuk Rancang Bangun Smartbike”. Jurnal Ilmu-Ilmu Teknik - Sistem , Vol. 12 No. 3.

[5] Rafiuddin Syam, PhD, 2013. "Dasar-dasara Teknik Sensor”.Fakultas Teknik Univ.Hasanuddin.

[6] Rusli Saputra, 2015. "Desain Sistem Informasi Order Photo Pada Creative Studio Photo dengan menggunakan bahasa Pemrograman Visaual basic. Jurnal Momentum, Vol.17. No.2 ISSN:1693-275X

[7] Jaenal Arifin, dkk. 2017. "Prototipe Pendingin Perangkat Telekomunikasi Sumber Arus Dc Menggunakan Smartphone”. Media Elektrika, Vol. 10, No. 1, Juni 2017 ISSN 2579-972X

[8] Roki Hardianto. 2019. Rancang Bangun Smart Lamp Menggunakan Micro Controller Arduino 
UNO. ZONAsi: Jurnal Sistem Informasi, Volume 1, Nomor 1, Mare 2019: 28-3

[9] Siti. 2017. "Implementasi Sensor Pir Pada Peralatan Elektronik Berbasis Microcontroller". Jurnal Inovtek Polbeng, VOL. 07, NO. 1. ISSN: 2088-6225. E-ISSN: 2580-2798

[10] Davis F. Sumajouw. (2015). Perancangan Sistem KeamananRumah Tinggal Terkendali Jarak Jauh. E-journal Teknik Elektro dan Komputer, ISSN : 2301-8402.

[11] Devid Prastyawan. (2012). Implementasi Model RobotEdukasi Menggunakan Mikrokontroler Atmega8 Untuk Robot Pemadam. Apijns- Indonesian Journal on Networking and Security ISSN: 2302- 5700.

[12] M. Dwisnanto Putra. (2017). Robot Pintar Penyambut Costumer pada Pusat Perbelanjaan Kota Manado. Jurnal Rekayasa Elektrika. Terakreditasi Ristekdikti No. 36b/E/KPT/2016. Volume 13 Nomor 1.

[13] Dicka. (2018). Aplikasi Sistem Lacak Kendaraan Berbasis Android Menggunakan Arduino Uno Dan Modul Sim808. urnal Ilmiah Teknologi dan Rekayasa . . 2018. DOI: 10.35760/tr.2018.v23i1.2451 